\title{
Zaburzenia języka i komunikacji w autyzmie i w zespole Aspergera
}

\section{Language and communication abnormalities in autism and Asperger Syndrome}

\author{
Izabela Chojnicka, Agata Szkiełkowska
}

Instytut Fizjologii i Patologii Słuchu, Światowe Centrum Słuchu, Klinika Audiologii i Foniatrii, Kajetany

Adres autora: Izabela Chojnicka, Światowe Centrum Słuchu, Klinika Audiologii i Foniatrii, ul. Mokra 17, Kajetany, 05-830 Nadarzyn, e-mail: i.chojnicka@ifps.org.pl

\section{Streszczenie}

Autyzm dziecięcy i zespół Aspergera to zaburzenia neurorozwojowe należące do grupy całościowych zaburzeń rozwojowych. Odrębność zespołu Aspergera i jego kryteria diagnostyczne od lat budzą kontrowersje wśród badaczy i klinicystów.

W pracy podjęto analizę potencjalnych różnic między autyzmem dziecięcym i zespołem Aspergera w sferze języka i komunikacji. Omawiane w artykule badania wskazują na brak jakościowych różnic między oboma zaburzeniami i na nieefektywność do niedawna obowiązujących kryteriów diagnostycznych ICD-10 i DSM-IV-TR. Wspierają zatem hipotezę dotyczącą kontinuum nieprawidłowości w obrębie zaburzeń ze spektrum autyzmu, aniżeli odrębność poszczególnych zaburzeń z grupy całościowych zaburzeń rozwojowych.

Słowa kluczowe: autyzm dziecięcy • zespół Aspergera • całościowe zaburzenia rozwojowe • zaburzenie ze spektrum autyzmu - zaburzenia języka i komunikacji

\begin{abstract}
Childhood autism and Asperger's syndrome are neurodevelopmental disorders from the group of pervasive developmental disorders. The distinction of Asperger's syndrome from autism and diagnostic criteria of Asperger's syndrome remains controversial among researchers and clinicians.

We aim to analyze the potential differences between childhood autism and Asperger's syndrome in the area of language and communication. Results discussed in the article indicate the lack of qualitative differences between the two disorders and the inefficiency of the recent diagnostic criteria from ICD-10 and DSM-IV-TR. Therefore they support the hypothesis concerning a continuum of impairments among autism spectrum, rather than distinction of disorders from the pervasive developmental disorders category.
\end{abstract}

Key words: childhood autism • Asperger's Syndrome • pervasive developmental disorders • autism spectrum disorder • language and communication impairments

\section{Wstęp}

Autyzm dziecięcy i zespół Aspergera to obecnie dwie odrębne jednostki nozologiczne należące do całościowych zaburzeń rozwojowych zgodnie z systemami klasyfikacji ICD-10 [1] i DSM-IV-TR [2]. Całościowe zaburzenia rozwojowe (ang. Pervasive Developmental Disorders, PDD) to grupa zaburzeń neurorozwojowych obejmujących jakościowe nieprawidłowości w trzech sferach, nazywanych też autystyczną triadą [3], wpływających na całościowe funkcjonowanie pacjenta. Nieprawidłowości w obszarze języka i komunikacji należą do jednego z trzech elementów autystycznej triady zaburzeń, obok nieprawidłowości w zakresie interakcji społecznych oraz ograniczonych, sztywnych wzorców zachowań i zainteresowań. Objawom PDD u 72\% przypadków towarzyszą inne zaburzenia psychiczne, neurorozwojowe czy zaburzenia zachowania, w tym zaburzenia snu, zaburzenia odżywiania, nadpobudliwość psychoruchowa, dysleksja, dyspraksja, zaburzenia lękowe i afektywne czy zaburzenie obsesyjno-kompulsywne [4]. Diagnostykę PDD komplikują także współwystępujące problemy poznawcze i niepełnosprawność intelektualna [5]. 
W przypadku autyzmu dziecięcego zaburzenia w obrębie języka i komunikacji zostały obszernie scharakteryzowane w literaturze naukowej, a poszczególne deficyty uwzględnione w kryteriach diagnostycznych klasyfikacji ICD-10 oraz DSM-IV-TR. W szczególności kryteria diagnostyczne ICD-10 autyzmu dziecięcego wskazują na jakościowe nieprawidłowości w obszarze komunikacji, obejmujące brak lub opóźnienie rozwoju mowy wraz z brakiem prób kompensowania deficytów za pomocą środków komunikacji niewerbalnej, takich jak gesty, kontakt wzrokowy czy ekspresja twarzy. Charakterystyczne jest także występowanie języka idiosynkratycznego, stereotypowego, powtarzalnego używania mowy, a także brak wzajemności w czasie konwersacji, z którym wiążą się trudności w inicjowaniu, podtrzymywaniu i zakańczaniu rozmowy z drugą osobą. U osób z autyzmem występują również echolalie bezpośrednie i odroczone, rytuały werbalne, używanie neologizmów czy nieprawidłowe używanie zaimków, obejmujące zastępowanie 1 osoby 2 lub 3 osobą (ty/on/ona zamiast ja). Nieprawidłowe mogą być również wzorce intonacyjne, wysokość, głośność oraz tempo wypowiedzi [5].

W przypadku zespołu Aspergera charakterystyka nieprawidłowości w obrębie języka i komunikacji jest niestety uboga, między innymi za sprawą kryteriów diagnostycznych zawartych w klasyfikacjach ICD-10 oraz DSM-IV-TR, w których opis sfery języka i komunikacji u osób z zespołem Aspergera ograniczony został do informacji o braku opóźnienia rozwoju mowy. Zawarte w klasyfikacjach diagnostycznych kryteria czasowe przesłoniły ocenę jakościową [6], bowiem jakość mowy i komunikacji osób z zespołem Aspergera różni się od mowy i komunikacji osób rozwijających się typowo.

\section{Jedno zaburzenie czy odrębne jednostki nozologiczne?}

Natężenie i wzorzec symptomów charakterystycznych dla całościowych zaburzeń rozwojowych znacząco różnią się u poszczególnych osób. W celu bardziej adekwatnego definiowania tej grupy zaburzeń stworzono pojęcie autystycznego kontinuum czy spektrum zaburzeń [4]. Klasyfikacja całościowych zaburzeń rozwojowych, a zwłaszcza miejsce zespołu Aspergera wśród zaburzeń ze spektrum autyzmu (ang. Autism Spectrum Disorders, ASD), budzi wiele kontrowersji wśród naukowców i klinicystów [7]. Niektórzy autorzy postulują stworzenie wydzielonych poza grupę całościowych zaburzeń rozwojowych kryteriów diagnostycznych przeznaczonych dla zespołu Aspergera [8], inni, akceptując przynależność zespołu Aspergera do grupy całościowych zaburzeń rozwojowych, wskazują jednocześnie na objawy odróżniające autyzm dziecięcy od zespołu Aspergera [6], przeciwstawiając się poglądom dotyczącym kontinuum pomiędzy autyzmem i zespołem Aspergera [9].

W przygotowywanym kolejnym wydaniu klasyfikacji Amerykańskiego Towarzystwa Psychiatrycznego DSM-5 podjęto decyzję o połączeniu dotychczas odrębnych jednostek z grupy całościowych zaburzeń rozwojowych w jedną - zaburzenie ze spektrum autyzmu [10]. Zaburzenie ze spektrum autyzmu ma zastąpić diagnozowane uprzednio: autyzm dziecięcy, zespół Aspergera, dziecięce zaburzenie dezintegracyjne oraz całościowe zaburzenia rozwojowe niezdiagnozowane inaczej. Autorzy zmian wyjaśniają podjętą decyzję tym, że wymienione zaburzenia reprezentują ich zdaniem kontinuum różniące się natężeniem objawów niż całkowicie odrębne jednostki nozologiczne. Ponadto podział spektrum zaburzeń autystycznych - poza spektrum cechuje się wyższą trafnością i rzetelnością niż podział na poszczególne zaburzenia, w przypadku których diagnozy wystawiane przez klinicystów opierają się częściej na głębokości objawów, poziomie umiejętności językowych i możliwościach intelektualnych niż na rzeczywistych cechach danego zaburzenia. Autorzy nowej wersji DSM-5 wskazują także, że jedno zaburzenie lepiej odzwierciedla wiedzę na temat patogenezy autyzmu i jego objawów klinicznych. Zaproponowane kryteria diagnostyczne zaburzenia ze spektrum autyzmu określają głębokość objawów oraz całościowy obraz rozwoju w dwóch sferach: społeczno-komunikacyjnej oraz ograniczonych wzorców zachowań i zainteresowań. Diagnoza kładąca nacisk na indywidualne różnice między osobami z ASD ma ułatwić planowanie interwencji terapeutyczno-medycznej. Przeprowadzone wstępne analizy wskazują, że zmiany kryteriów nie wpłyną na liczbę diagnozowanych dzieci [10].

W przypadku zespołu Aspergera autorzy nowych kryteriów powołują się na badania wskazujące nieefektywność kryteriów zespołu Aspergera w DSM-IV dla klinicystów [11,12]. W szczególności problemy dotyczą uzyskiwania dokładnych informacji dotyczących historii wczesnego rozwoju języka i komunikacji w przypadku starszych dzieci i dorosłych, przy czym średni wiek osoby, w którym zespół Aspergera jest u niej diagnozowany, wynosi ok. 7 lat [13]. Opóźnienie rozwoju mowy, które nie występuje zgodnie z kryteriami diagnostycznymi w zespole Aspergera, nie musi także wystąpić w przypadku autyzmu dziecięcego. Dlatego, aby osoba otrzymała diagnozę zespołu Aspergera, nie powinna spełniać kryteriów dla autyzmu z obszaru komunikacji. W praktyce trudności w inicjowaniu i utrzymywaniu konwersacji z drugą osobą występują na ogół nawet u wysokofunkcjonujących osób z zespołem Aspergera. W efekcie diagnoza zespołu Aspergera przyznawana jest w sposób nieścisły. W badaniach Williamsa i wsp. [14] pokazano, że spośród 348 dzieci badanych przez 466 specjalistów, 44\% dzieci, które otrzymały diagnozę zespołu Aspergera, autyzmu atypowego lub innych całościowych zaburzeń rozwojowych, spełniało kryteria autyzmu dziecięcego.

\section{Język i komunikacja w autyzmie dziecięcym i w zespole Aspergera}

Choć w kryteriach diagnostycznych ICD-10 i DSM-IV-TR brak jest informacji na temat nieprawidłowości w obszarze języka i komunikacji u osób z zespołem Aspergera, jakościowe zaburzenia w tej sferze występują powszechnie w tej grupie pacjentów. Warto spróbować odpowiedzieć na pytanie, czy zaburzenia te są wspólne dla autyzmu i zespołu Aspergera.

Obserwacja kliniczna osób z zespołem Aspergera potwierdza występowanie trudności w sferze komunikacyjnej podobnych jak u osób z autyzmem. Osoby z zespołem Aspergera mają trudności z inicjowaniem i prowadzeniem rozmowy, nie odczytują sygnałów społecznych wysyłanych przez rozmówcę, przez co prowadzona przez nich rozmowa pozbawiona jest wzajemności. Zdarza się też, że u osoby 
z zespołem Aspergera występuje język idiosynkratyczny i/lub stereotypowy, neologizmy czy echolalie [15]. Nieprawidłowości dotyczą również komunikacji niewerbalnej.

We wczesnych pracach (przed opracowaniem obowiązujących obecnie kryteriów klasyfikacji ICD-10 i DSM-IV-TR) poświęconych różnicom między zespołem Aspergera a autyzmem sugerowano, że osoby z zespołem Aspergera wykazują większe zdolności werbalne niż osoby z autyzmem [16]. Po opublikowaniu nowych kryteriów diagnostycznych nie potwierdzano uprzednio obserwowanych różnic [17].

W innych pracach $[18,19]$ prezentowano wyniki, w których dzieci z zespołem Aspergera w wieku przedszkolnym wykazywały lepsze rozumienie mowy niż dzieci z autyzmem wysokofunkcjonującym (któremu nie towarzyszą obniżone możliwości intelektualne, ang. High-Functioning Autism, HFA). Niestety niejasne kryteria diagnostyczne zespołu Aspergera sprawiają, że klinicyści rozróżniają zespół Aspergera i autyzm głównie na podstawie umiejętności językowych dziecka [17], co mogło wypłynąć na opisane obserwacje. W wymienionych badaniach nie przeprowadzono też porównania $\mathrm{z}$ dziećmi rozwijającymi się typowo.

Fine i wsp. [20] wskazywali na zubożoną intonację u osób $\mathrm{z}$ autyzmem wysokofunkcjonującym $\mathrm{w}$ przeciwieństwie do osób z zespołem Aspergera. Z kolei Gillberg [22] opisywał występowanie bardziej płaskiej, monotonnej intonacji i nieprawidłowej wysokości głosu u osób z zespołem Aspergera, choć u osób z HFA nieprawidłowości były bardziej wyraźne. Shriberg i wsp. [23] porównywali wzorce prozodii u osób z autyzmem wysokofunkcjonującym i u osób z zespołem Aspergera oraz u osób rozwijających się typowo w wieku od 10 do 50 lat. W porównaniu $\mathrm{z}$ osobami o typowym rozwoju zarówno u osób z zespołem Aspergera, jak i z autyzmem wysokofunkcjonującym częściej występowały niewielkie zniekształcenia artykulacyjne, niezrozumiałe wypowiedzi spowodowane ograniczonym dyskursem, jak również wypowiedzi uznane za niewłaściwe ze względu na obecność nieprawidłowości służących do eksponowania znaczenia komunikatów akcentowania, frazowania i rezonansu. Ponadto mowa osób z zespołem Aspergera miała większą głośność niż osób $\mathrm{z}$ autyzmem wysokofunkcjonującym.

W innych badaniach wskazywano na podobieństwa między zespołem Aspergera a autyzmem w zakresie występowania echolalii, zamiany zaimków oraz używania neologizmów [12]. Z kolei Gilchrist i wsp. [24] wskazywali na częstsze występowanie echolalii i zamiany zaimków w autyzmie w porównaniu z zespołem Aspergera, podobnie jak większych nieprawidłowości w zakresie używania gestów konwencjonalnych. Osoby z autyzmem nie różniły się jednak od osób z zespołem Aspergera w zakresie używania rytuałów werbalnych, wypowiedzi stereotypowych czy zadawania niestosownych społecznie pytań. Z wiekiem różnice między grupami zanikały. W okresie dorastania jedyną zaobserwowaną przez Gilchrist i wsp. różnicą była większa tendencja do angażowania się osób z zespołem Aspergera w rozmowy o charakterze społecznym.

Obserwowane różnice w zakresie rozumienia i ekspresji mowy między osobami z zespołem Aspergera i z autyzmem wysokofunkcjonującym zanikają, gdy uczestnicy badania są dobrani pod względem ilorazu inteligencji i są w starszym wieku. W badaniu Howlin [25] analiza wyników uzyskiwanych w wystandaryzowanym wywiadzie ADI-R (ang. Autism Diagnostic Interview-Revised) przez dorosłe osoby z autyzmem wysokofunkcjonującym, u których wystąpiło opóźnienie rozwoju mowy, i przez dorosłe osoby z zespołem Aspergera nie pokazała istotnych statystycznie różnic zarówno dla wyniku ogólnego, jak i wyników poszczególnych skal. W szczególności wyniki w pozycjach dotyczących rozumienia mowy i ekspresji językowej były zbliżone, choć umiejętności językowe w obu grupach znalazły się poniżej umiejętności dla danego wieku chronologicznego.

Choć uzyskiwane przez dzieci z zespołem Aspergera i autyzmem wysokofunkcjonującym wyniki ogólne na skalach inteligencji są zbliżone, analiza profilowa wskazuje na występujące między nimi różnice [21]. Porównanie wyników osób z autyzmem wysokofunkcjonującym i osób z zespołem Aspergera uzyskiwanych w Skali Inteligencji Wechslera [26] wykazało istotnie wyższe wyniki na Skali Słownej u osób z zespołem Aspergera niż na Skali Bezsłownej. Wyniki na Skali Słownej uzyskiwane przez osoby z zespołem Aspergera były wyższe od wyników uzyskiwanych przez osoby z HFA, w szczególności w testach Wiadomości, Słownik i Arytmetyka.

Badano również strukturalne zaburzenia językowe u osób $\mathrm{z}$ autyzmem wysokofunkcjonującym i zespołem Aspergera, obejmujące deficyty w poprawnym używaniu gramatyki i składni, ale nie w semantycznych, ani pragmatycznych aspektach języka [27]. Umiejętności językowe badano u uczestników projektu w wieku 4-6 lat, a następnie 2 lata później za pomocą Test of Language Development-2 (TOLD-2). Równocześnie co dwa lata, aż do osiągnięcia przez uczestników wieku 15-17 lat, badano symptomy charakterystyczne dla ASD i zachowania adaptacyjne za pomocą Autism Behavior Checklist (ABC) oraz Vineland Adaptive Behavior Scales (VABS). Umożliwiło to ocenę długoterminowego funkcjonowania osób badanych w odniesieniu do ich umiejętności językowych w dzieciństwie. Okazało się, że strukturalne zaburzenia językowe w wieku 6-8 lat były lepszym predyktorem natężenia symptomów ASD i trudności adaptacyjnych w okresie dojrzewania niż diagnoza zespołu Aspergera czy autyzmu bazująca na kryteriach DSM-IV. Może to oznaczać, że nieprawidłowe posługiwanie się gramatyką i składnią może być lepszym predyktorem objawów autystycznych niż opóźnienie rozwoju mowy przed 3 rokiem życia.

Ciekawe jest także porównanie przetwarzania mowy i sygnałów dźwiękowych u osób $\mathrm{z}$ autyzmem i zespołem Aspergera. W badaniach Speirs i wsp. [28] analizowano przetwarzanie leksykalne u osób z autyzmem wysokofunkcjonującym, zespołem Aspergera oraz osób o typowym rozwoju. W przeciwieństwie do osób $\mathrm{z}$ autyzmem wysokofunkcjonującym, u osób z zespołem Aspergera i osób rozwijających się typowo nie zaobserwowano nieprawidłowości przetwarzania leksykalnego.

$\mathrm{W}$ innych badaniach sprawdzano różnice w przetwarzaniu słuchowym u pacjentów z autyzmem, zespołem Aspergera oraz osób rozwijających się typowo [29]. Badano analizowanie wysokości, barwy oraz głośności 
dźwięków. Prezentowane bodźce zawierały proste i złożone tony $\mathrm{w}$ analizie czasowo-częstotliwościowej. Osoby $\mathrm{z}$ autyzmem, w przeciwieństwie do osób z zespołem Aspergera, uzyskiwały lepsze wyniki dla rozróżniania wysokości tonów prostych, ale nie tonów złożonych. Według autorów uwydatnione rozróżnianie wysokości dźwięków może stanowić korelat poznawczy opóźnienia rozwoju mowy u osób z całościowymi zaburzeniami rozwojowymi.

\section{Dyskusja}

Choć autyzm dziecięcy i zespół Aspergera to obecnie odrębne jednostki nozologiczne w klasyfikacjach zaburzeń psychicznych ICD-10 [1] i DSM-IV-TR [2], trwają prace nad połączeniem ich, wraz z innymi zaburzeniami z grupy całościowych zaburzeń rozwojowych, w jedno zaburzenie - zaburzenie ze spektrum autyzmu [10]. Zarówno odrębność zespołu Aspergera, jak i jego kryteria diagnostyczne od lat budzą kontrowersje wśród badaczy i klinicystów [7].

Wiele powodów determinuje istotność odpowiedzi na pytanie, czy autyzm i zespół Aspergera to odrębne zaburzenia, czy jedno kontinuum objawów [21]. Jeżeli osoby z zespołem Aspergera cechowałyby jakościowo odmienne nieprawidłowości niż osoby $\mathrm{z}$ autyzmem, oznaczałoby to w konsekwencji odmienne potrzeby w zakresie leczenia i terapii. Jeżeli jednak obserwowane w zespole Aspergera symptomy przypominają te obserwowane w autyzmie, można czerpać $\mathrm{z}$ wiedzy dotyczącej autyzmu w przypadku interwencji wobec osób z zespołem Aspergera. Jeśli uznamy oba zaburzenia za odrębne, możemy przypuszczać, że etiopatogeneza leżąca u ich podłoża także jest inna. Wiedza na temat etiologii obu zaburzeń może wspierać wczesne rozpoznawanie dzieci z podwyższonym ryzykiem wystąpienia któregoś z zaburzeń, wczesną diagnozę osób wykazujących symptomy autyzmu/zespołu Aspergera, przewidywanie współwystępowania innych zaburzeń psychiatrycznych, jak również identyfikację potencjalnych środków prewencyjnych [21]. Odrębność obu zaburzeń rzutowałaby także na prognozę funkcjonowania osoby z procesie rozwoju.

Badania naukowe i praktyka kliniczna wskazują, że obecne kryteria różnicujące zespół Aspergera i autyzm są nieodpowiednie. Obecność lub brak opóźnienia rozwoju mowy na wczesnych etapach rozwoju nie jest dobrym wskaźnikiem profilu symptomów charakterystycznych dla zaburzeń ze spektrum autyzmu w późniejszym życiu, a różnice między autyzmem i zespołem Aspergera, podzielonych względem opóźnienia rozwoju mowy, są niejednoznaczne [17]. Sam Hans Asperger wskazywał na obecność u jego pacjentów dysfunkcji w obszarze języka i komunikacji oraz opóźnienie rozwoju mowy [30]. Co więcej, informacje na temat wczesnego rozwoju mowy są na ogół uzyskiwane retrospektywnie, z czym wiąże się szereg problemów. Rodzice/opiekunowie mogą nie pamiętać terminów opanowywania rozwojowych kamieni milowych, a drobne opóźnienia mogą być wyolbrzymiane. Co więcej, obecne funkcjonowanie dziecka może wpływać na ocenę funkcjonowania w przeszłości [17].

Przegląd badań dotyczących jakościowych nieprawidłowości w sferze języka i komunikacji wskazuje na brak zasadniczych różnic między autyzmem i zespołem Aspergera. Niektóre z objawów, takie jak nieprawidłowości intonacyjne [22], występowanie echolalii, neologizmów czy zamiany zaimków [24], w niektórych badaniach były bardziej wyraźne u osób $\mathrm{z}$ autyzmem, jednak występowały również u osób z diagnozą zespołu Aspergera. Z kolei nieprawidłowości w obrębie prozodii [23], występowanie wypowiedzi stereotypowych, powtarzających się, rytuałów werbalnych czy komentarzy niestosownych społecznie [24] istniały w podobnym natężeniu zarówno u osób $\mathrm{z}$ autyzmem, jak i z zespołem Aspergera. Różnice między omawianymi zaburzeniami zacierają się zwłaszcza, gdy w badaniach porównywani są pacjenci starsi - młodzież i osoby dorosłe $\mathrm{z}$ uwzględnieniem ilorazu inteligencji.

Zatem badania poświęcone zaburzeniom języka i komunikacji w autyzmie dziecięcym i zespole Aspergera wskazują raczej na kontinuum nieprawidłowości w tym zakresie niż odrębne jednostki nozologiczne, a pewne subtelne różnice obserwowane w części prac nie mają zastosowania jako kryteria różnicujące oba zaburzenia. Ma to zasadnicze znaczenie w kontekście kryteriów diagnostycznych kolejnego wydania klasyfikacji DSM-5, która ukazała się w maju 2013 r., a także projektów naukowych poświęconych poszukiwaniu przyczyn zaburzeń ze spektrum autyzmu i planowania interwencji wobec osób z ASD.

\section{Piśmiennictwo:}

1. World Health Organization. International classification of diseases: Diagnostic criteria for research ( $10^{\text {th }}$ edition) Geneva Switzerland: World Health Organization; 1992.

2. American Psychiatric Association. Diagnostic and statistical manual of mental disorders ( $4^{\text {th }}$ ed TR) Washington DC: American Psychiatric Association; 2000.

3. Pisula E. Autyzm. Przyczyny symptomy terapia. Gdańsk: Wydawnictwo Harmonia; 2010.

4. Yates K, Le Couteur A. Diagnosing autism. Paediatr Child Health, 2009; 19: 55-59.

5. Pisula E. Małe dziecko z autyzmem. Gdańsk: Gdańskie Wydawnictwo Psychologiczne; 2005.

6. Korendo M. Kryteria diagnozy różnicowej autyzmu i zespołu Aspergera. Nowa Logopedia, 2012; 3: 249-57.
7. Bryńska A. Miejsce zespołu Aspergera w grupie całościowych zaburzeń rozwoju: kontinuum czy spektrum zaburzeń autystycznych? Psychiatria Polska, 2011; 45: 749-58.

8. Gillberg C, Gillberg IC. Asperger syndrome - some epidemiological considerations: A research note. J Child Psychol Psychiatry, 1989; 30(4): 631-38.

9. Schopler E. Are autism and Asperger syndrome (AS) different labels or different disabilities? J Aut Dev Disord, 1996; 26(1): 109-10.

10. American Psychiatric Association. Diagnostic and Statistical Manual of Mental Disorders Fifth Edition; 2011 http://wwwdsm5org/proposedrevision/pages/proposedrevisionasp $x$ ?rid $=94$ 20111112

11. Mayes SD, Calhoun SL, Crites DL. Does DSM-IV Asperger's disorder exist? J Abnorm Child Psychol, 2001; 29(3): 263-71. 
12. Miller JN, Ozonoff S. The external validity of Asperger disorder: lack of evidence from the domain of neuropsychology. J Abnorm Psychol, 2000; 109(2): 227-38.

13. Mandell DS, Thompson WW, Weintraub ES, Destefano F, Blank MB. Trends in diagnosis rates for autism and ADHD at hospital discharge in the context of other psychiatric diagnoses. Psychiatr Serv, 2005; 56(1): 56-62.

14. Williams K, Tuck M, Helmer M, Bartak L, Mellis C, Peat JK. Autism Spectrum Disorder Steering Group. Diagnostic labelling of autism spectrum disorders in NSW. J Paediatr Child Health, 2008; 44(3): 108-13.

15. Atwood T. The Complete Guide to Asperger's Syndrome. London; Philadelphia: Jessica Kingsley Publishers; 2007.

16. Ozonoff S, Rogers SJ, Pennington BF. Asperger's syndrome: Evidence of an empirical distinction from highfunctioning autism. J Child Psychol Psychiatry, 1991; 32(7): 1107-22. Za: Sanders JL. Qualitative or quantitative differences between Asperger's disorder and autism? Historical considerations. J Autism Dev Disord, 2009; 39(11): 1560-67.

17. Sanders JL. Qualitative or quantitative differences between Asperger's disorder and autism? Historical considerations. J Autism Dev Disord, 2009; 39(11): 1560-67.

18. Iwanaga R, Kawasaki C, Tsuchida R. Brief report: Comparison of sensory-motor and cognitive function between autism and Asperger syndrome in preschool children. J Autism Dev Disord, 2000; 30(2): 169-74.

19. Szatmari P, Bryson SE, Boyle MH, Streiner DL, Duku E. Predictors of outcome among high functioning children with autism and Asperger syndrome. J Child Psychol Psychiatry, 2003; 44(4): 520-28.

20. Fine J, Bartolucci G, Ginsberg G, Szatmari P. The use of intonation to communicate in pervasive developmental disorders. J Child Psychol Psychiatry, 1991; 32(5): 771-82. Za: Macintosh KE, Dissanayake C. Annotation: The similarities and differences between autistic disorder and Asperger's disorder: a review of the empirical evidence. J Child Psychol Psychiatry, 2004; 45(3): 421-34.

21. Macintosh KE, Dissanayake C. Annotation: The similarities and differences between autistic disorder and Asperger's disorder: a review of the empirical evidence. J Child Psychol Psychiatry, 2004; 45(3): 421-34.
22. Gillberg C. Asperger syndrome in 23 Swedish children. Dev Med Child Neurol, 1989; 31(4): 520-31. Za: Macintosh KE, Dissanayake C. Annotation: The similarities and differences between autistic disorder and Asperger's disorder: a review of the empirical evidence. J Child Psychol Psychiatry, 2004; 45(3): 421-34.

23. Shriberg LD, Paul R, McSweeny JL, Klin AM, Cohen DJ, Volkmar FR. Speech and prosody characteristics of adolescents and adults with high-functioning autism and Asperger syndrome. J Speech Lang Hear Res, 2001; 44(5): 1097-115.

24. Gilchrist A, Green J, Cox A, Burton D, Rutter M, Le Couteur A. Development and current functioning in adolescents with Asperger syndrome: a comparative study. J Child Psychol Psychiatry, 2001; 42(2): 227-40.

25. Howlin P. Outcome in high-functioning adults with autism with and without early language delays: implications for the differentiation between autism and Asperger syndrome. J Autism Dev Disord, 2003; 33(1): 3-13.

26. Ghaziuddin M, Mountain-Kimchi K. Defining the intellectual profile of Asperger syndrome: Comparison with high-functioning autism. J Autism Dev Disord, 2004; 34(3): 279-84. Za: Sanders JL. Qualitative or quantitative differences between Asperger's disorder and autism? Historical considerations. J Autism Dev Disord, 2009; 39(11): 1560-67.

27. Bennett T, Szatmari P, Bryson S, Volden J, Zwaigenbaum L, Vaccarella L i wsp. Differentiating autism and Asperger syndrome on the basis of language delay or impairment. J Autism Dev Disord, 2008; 38(4): 616-25.

28. Speirs S, Yelland G, Rinehart N, Tonge B. Lexical processing in individuals with high-functioning autism and Asperger's disorder. Autism, 2011; 15(3): 307-25.

29. Bonnel A, McAdams S, Smith B, Berthiaume C, Bertone A, Ciocca V i wsp. Enhanced pure-tone pitch discrimination among persons with autism but not Asperger syndrome. Neuropsychologia, 2010; 48(9): 2465-75.

30. Asperger H. Die autistischen Psychopathen im Kindesalter Arch Psychiatr Nervenkr, 1944; 17776-137. Za: Atwood T. The Complete Guide to Asperger's Syndrome. London; Philadelphia: Jessica Kingsley Publishers; 2007. 